\title{
Kernos
}

Revue internationale et pluridisciplinaire de religion grecque antique

31 | 2018

Varia

\section{A Dedication of a Naos to Skorpon's Ourania in Ascalon (Ashkelon)}

Avner Ecker, Hannah M. Cotton, Saar Ganor and David J. Wasserstein

\section{(2) OpenEdition}

\section{Journals}

Electronic version

URL: http://journals.openedition.org/kernos/2696

DOI: 10.4000/kernos.2696

ISSN: 2034-7871

\section{Publisher}

Centre international d'étude de la religion grecque antique

\section{Printed version}

Date of publication: 1 December 2018

Number of pages: 111-118

ISBN: 978-2-87562-055-2

ISSN: 0776-3824

\section{Electronic reference}

Avner Ecker, Hannah M. Cotton, Saar Ganor and David J. Wasserstein, "A Dedication of a Naos to Skorpon's Ourania in Ascalon (Ashkelon)", Kernos [Online], 31 | 2018, Online since 01 October 2020, connection on 25 January 2021. URL: http://journals.openedition.org/kernos/2696 ; DOI: https:// doi.org/10.4000/kernos.2696

This text was automatically generated on 25 January 2021.

Kernos 


\title{
A Dedication of a Naos to Skorpon's Ourania in Ascalon (Ashkelon)
}

\author{
Avner Ecker, Hannah M. Cotton, Saar Ganor and David J. Wasserstein
}

We dedicate this article to Professor Benjamin Isaac, a friend and a colleague of many years. This article started its life at a conference held in his honour at Tel Aviv University on the occasion of his retirement. It was during that conference that Professor Angelos Chaniotis saved us from an egregious mistake and made us change the entire interpretation of the inscription discussed here. We wish to thank Avshalom Karasik (The National Laboratory for Digital Documentation, Israel Antiquities Authority) for the image produced using D.o.R. technique (= Drawing over Reliefs), which greatly helped in verifying the readings on the stone. On the technique see GILBOA, TAL, SHIMSHONI, KOLOMENKIN (2013). Last but not least we thank Yael Yolovitch of the Israel Antiquities Authority and Ofer Pogorelsky of the Hebrew University for their kindness and assistance.

1 Louis Nicolas Philippe Auguste, Comte de Forbin (1779-1841), director of the Louvre museums, visited the ruins of Ascalon in 1818. ${ }^{1}$ Having read his Herodotus, he tagged the debris of a grand colonnaded building as the temple of Aphrodite, for indeed this is

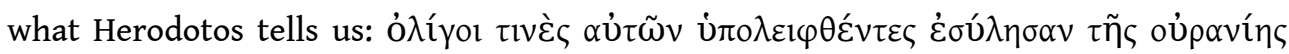

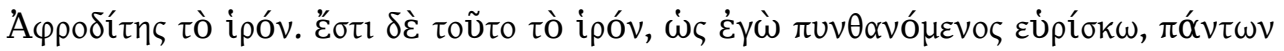

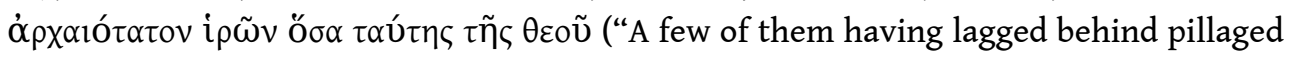
the temple of celestial Aphrodite. I have inquired and found that the temple at Ascalon is the most ancient of all the temples to this goddess"). Notwithstanding this impression, and that of subsequent nineteenth-century travellers and explorers, to date no such temple has been discovered in archaeological excavations in Ascalon. ${ }^{2}$

2 The inscribed marble gable published here for the first time was found some twenty five years ago in the course of construction work northeast of the ancient city center of Ascalon (approximate map ref. 158206/619464), in the necropolis, about 700 meters outside the modern city of Ascalon. It disappeared shortly after its discovery, but recently it has resurfaced and reached the Israel Antiquities Authority. It is now on display at the Rockefeller Museum, in Jerusalem. 
The gable, of the Syrian type, is $132 \mathrm{~cm}$ wide, $65 \mathrm{~cm}$ high and $17 \mathrm{~cm}$ thick at its base, tapering to $10 \mathrm{~cm}$ thick at the top. The arch is $40 \mathrm{~cm}$ wide. The front, unlike the back, is chipped in some places, especially on the left-hand side. Its face is finely worked: a four-petal flower $(12 \times 12 \mathrm{~cm})$ is placed right below the peak. A six-line inscription occupies almost the whole surface. The seventh line runs along the top fascia of the base, on either side of the curved part of the fascia.

The back, though preserved intact, is roughly worked with a stepped border cut to fit into a niche. Three sockets are carved into the top of the gable, a rectangular socket on each edge $(5 \times 3 \mathrm{~cm}$, preserved depth: $4 \mathrm{~cm})$ and a third trapezoidal socket in the center behind the apex $(10 \times 7 \mathrm{~cm})$. Several decorative incisions, each ca. $20 \mathrm{~cm}$ long and $2 \mathrm{~cm}$ wide, run along the base; the space between these incisions was occupied by the capitals of four colonnettes or small pilasters.

5 The entire artifact, a piece of marble veneer fitted on and into a stone wall over a niche, is likely to have occupied either the outer wall of a small temple, or the wall of a precinct; alternatively, it may have been part of a free-standing aedicule. ${ }^{3}$

6 The text is almost complete, save for 3-4 letters on the left-hand side of 1.5, and 810 letters in the last line inscribed on the fascia. The letters are 4-6 cm high.

$1 \mathrm{M} \cdot \mathrm{AYP}^{\prime} \cdot \mathrm{MAPI} \Omega \mathrm{N}$ KAI

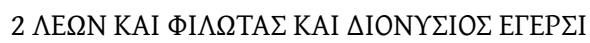

3 $\Theta E O I \triangle I O N Y \Sigma I O Y$ TH OYPANIA $\Theta E \Omega \Sigma$ KOPП $\Omega$ NO $\Sigma$

4 ËK T $\Omega$ N I $\triangle I \Omega N$ TON NAON $\Sigma Y N$ ПANTI KA

5 [3-4 letters]PГ $\Omega$ E $\Xi$ ENTO $\Lambda$ H $\Sigma \Delta$ IONY $\Sigma I O Y ~ \Pi A$

6 TPO $\Sigma$ AYT $\Omega$ N

7 [8-10 letters] $\Lambda \Omega$ TA $\Lambda$ EONTO $\Sigma$ ETOY $\Sigma \cdot \Gamma \mathrm{K} \mathrm{T} \cdot$ YMEPBEPETAIOY

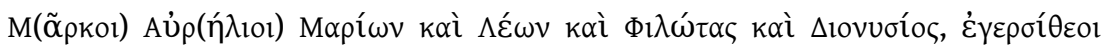

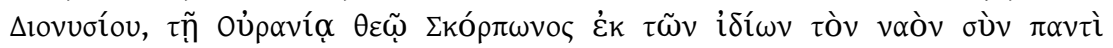

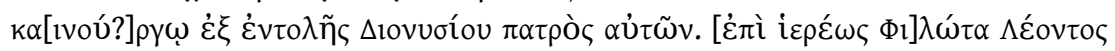

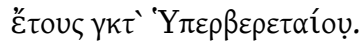

M. Aurelius Marion and (M. Aurelius) Leon and (M. Aurelius) Philotas and (M. Aurelius) Dionysios, egersitheoi of the Dionysion, ${ }^{4}$ [erected] to the Goddess Ourania of Skorpon at their own expense the temple, with all novelty of work, according to the testament of Dionysios, their father. (In the year) when Philotas son of Leon was priest. Year 323 (of the era of Ascalon), in the month of Hyperberetaios (= mid-September to mid-October AD 220).

\section{Commentary}

Lines 2-3: ЕГЕРЕIӨЕОI: The term $\dot{\varepsilon} \gamma \varepsilon \rho \sigma i ́ \theta \varepsilon O \zeta$ is not recorded in LSJ, where we find only

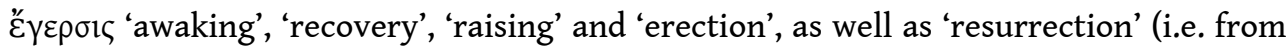
death: Matt. 27.53). Its meaning is clear though when one looks at the other combinations of ЕГЕР $\Sigma$ I with a noun in LSJ s.v. The word is found, however, in a papyrus from the mid-third century BC of the Zenon archive (P.Cair. Zen. 1, 59009 Fr. A:

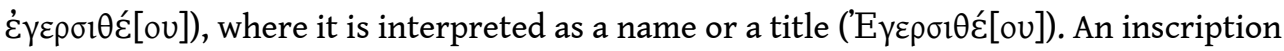
from Philadelphia/Amman preserves part of this title as well, as it records an

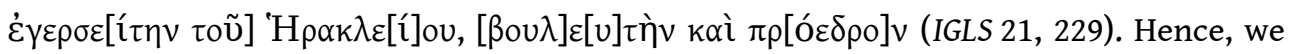
suggest translating it as 'god awakeners' or 'god resurrectors'.

7 More relevant for the present discussion is the appearance of the title in two inscriptions, which like ours also come from Ascalon. They were edited by Werner Eck in the third volume of the Corpus Inscriptionum Iudaeae/Palaestinae (CIIP): 


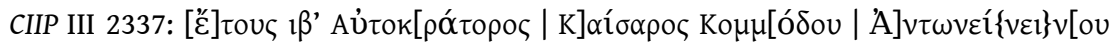

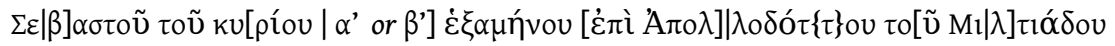

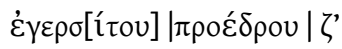

In the twelfth year of Imperator Caesar Commodus Antoninus Augustus, our Lord, in the first (or) second half of the year, when Apollodotus son of Miltiades was in charge of the works as prohedros. Seventh (column).

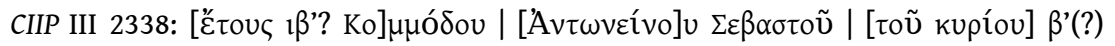

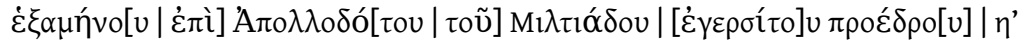

In the twelfth year of Commodus Antoninus Augustus, our Lord, in the second(?) half of the year, when Apollodotus son of Miltiades was responsible for the work when he was prohedros. Eighth (column).

8 Eck observes there that they belong to the same building where they stood as the seventh and eighth columns in a row. ${ }^{5}$ He took the nominative to be $\dot{\varepsilon} \varepsilon \rho \sigma[i$ in $\zeta] ;$ the new inscription, however, suggests that in no. 2337, as well as in no. 2338 , we should read: $\dot{\varepsilon} \gamma \varepsilon \rho \sigma[i ́ \theta \varepsilon \circ \varsigma]$.

Egersis is an awakening, and a religious term for resurrection (e.g. Matt. 27.53). The Tyrian god Melqart is perhaps the best known god to have an egersis ritual festival: the god was resurrected annually-probably by a high ranking priest. The festival was allegedly founded by none other than king $\mathrm{H}$ 區iram of Tyre in the tenth century BC. ${ }^{6}$ Melqart and Astarte were ritually resurrected in Carthage by officiants called literally 'god awakeners' (םלא מקמ).?

The inscription published here for the first time, together with the evidence of CIIP III 2337 and 2338, vindicates Bonnet's claim, made already in 1988, for the existence of these officials in Ascalon. ${ }^{8}$

Lines 2-3: $\triangle I O N Y \Sigma I O Y$ : our punctuation, and consequently also our translation, ignores the absence of the definite article, toũ, before $\Delta$ lovvoíov, i.e. egersitheoi of the

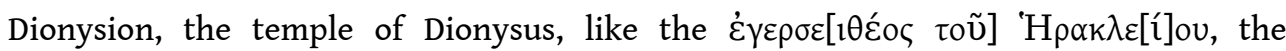
egersitheos of the Temple of Heracles, in IGLS 21, 229. For the annual resurrection of Dionysus see Plutarch, Isis and Osiris 365. This is the first piece of evidence for the existence of the Egersitheoi of Dionysus in Ascalon.

11 The egersis of Dionysus requires further study. However, here we may content ourselves with the observation that Orphic texts represent Dionysus as a "Dying God", annually resurrected. ${ }^{9}$ More importantly, Plutarch equates Dionysus with Osiris, with the observation that the followers of Dionysus habitually "wake ( $\dot{\varepsilon} \gamma \varepsilon i ́ p \omega \sigma \mathrm{l})$ the god of the

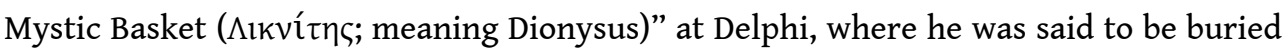
(Plut. Is. 365). An awakening ritual of Dionysus seems to have taken place also in Rhodes, as recorded on a third-century inscription, in which a priest of Dionysus, who made many contributions to the temple and the city, was honoured by the people and the council of Rhodes. One of his contributions concerned a waterpipe organ used for

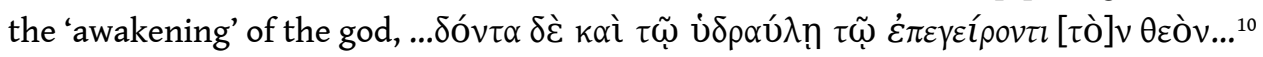

In the case of Ascalon the possibility that Dionysus is an interpretatio graeca of Osiris must be considered, for this took place in several other cities along the Phoenician coast. ${ }^{11}$ Last but not least, this may explain the connection between Dionysus and Ourania of Scorpon, since the latter may well be a Greek manifestation of Isis.

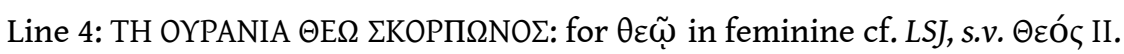




\section{mythological founder of the cult of Ourania in Ascalon, or a citizen of Ascalon who re- founded the cult of the Goddess in Ascalon, cannot be decided.}

$\Sigma \kappa o ́ p \pi \omega v$ is the personal name of the founder of the cult. ${ }^{12}$ Whether Skorpon was the

We have found only three other attestations of the name: in the third/second century BC in Karpathos, the second/first century BC in Rhodes, and in the first century AD in Stratonikeia in Caria. The relative proximity of these places, combined with the rarity of the name, makes it plausible that it originated in the Dodecanese islands or in southwestern Asia Minor.

Lines 4-5: $\Sigma$ YN ПАNTI КА[INOY]РГ $\Omega$, "with all novelty", is pure conjecture; cf. an inscription dated to AD 558/9 from the baths of lepers at Scythopolis, ${ }^{13}$ where $\lambda$ ovt $\rho \grave{\alpha}$

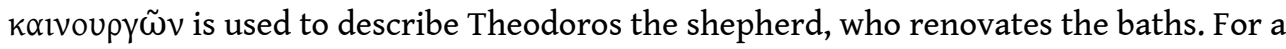
similar construction see SEG 32, 1269 (Phrygia, Roman Imperial period): $A \lambda \varepsilon ́ \xi \alpha v \delta \rho \circ \varsigma$

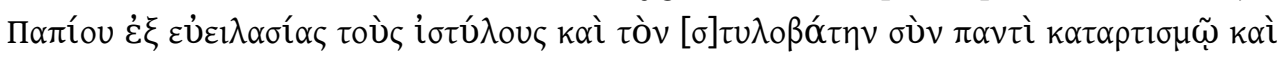

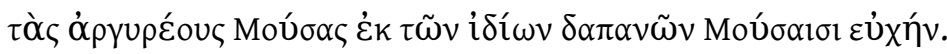

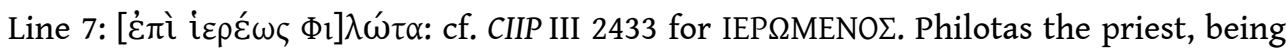
son of Leo, is not identical with his homonym in the first line. As for Ětouৎ $\gamma \kappa \tau^{\prime}$ 'Y $\pi \varepsilon \beta \varepsilon \varepsilon \rho \varepsilon \tau \alpha$ íou, scil. of the era of Ascalon, 104/103 BC, see Maimaris ${ }^{14}$ and Isaac in CIIP III p. 242 at n. 38.

15 Are we in the presence of a private cult, i.e. one restricted to the family of the founder of the cult, namely Skorpon, or is the goddess worshipped by the general public as well? The answer is that we simply do not know, and so far have no way of finding out. Nor can we offer an explanation for the involvement of the egersitheoi of the temple of Dionysus with the cult/temple of Ourania of Skorpon.

However, in Ascalon Ourania Aphrodite was a resident deity. ${ }^{15}$ Herodotus (1.105) describes her temple there as "the most ancient of all the temples to this goddess". She also appears in dedications by the people of Ascalon in second-century BC Delos, where she may be equated also with 'Palestinian Astarte'. ${ }^{16}$ Philo tells us that the Dove, sacred to Aphrodite (and to Derketo-Atargatis), was sacred in this city (De Providentia, 64). Finally, Pausanias observes that the people of Ascalon were among those who celebrated the worship of the goddess in times before his own; he does not make it clear, however, whether or not her veneration in the city continued down to his own day. ${ }^{17}$ We now have the proof that it did.

Finally, and perhaps most importantly, if this inscription indeed comes from a chapel dedicated to Aphrodite, then it constitutes the first - and so far only - tangible piece of evidence confirming the ancient ties linking Ourania-Aphrodite and Ascalon. 


\section{Illustrations}

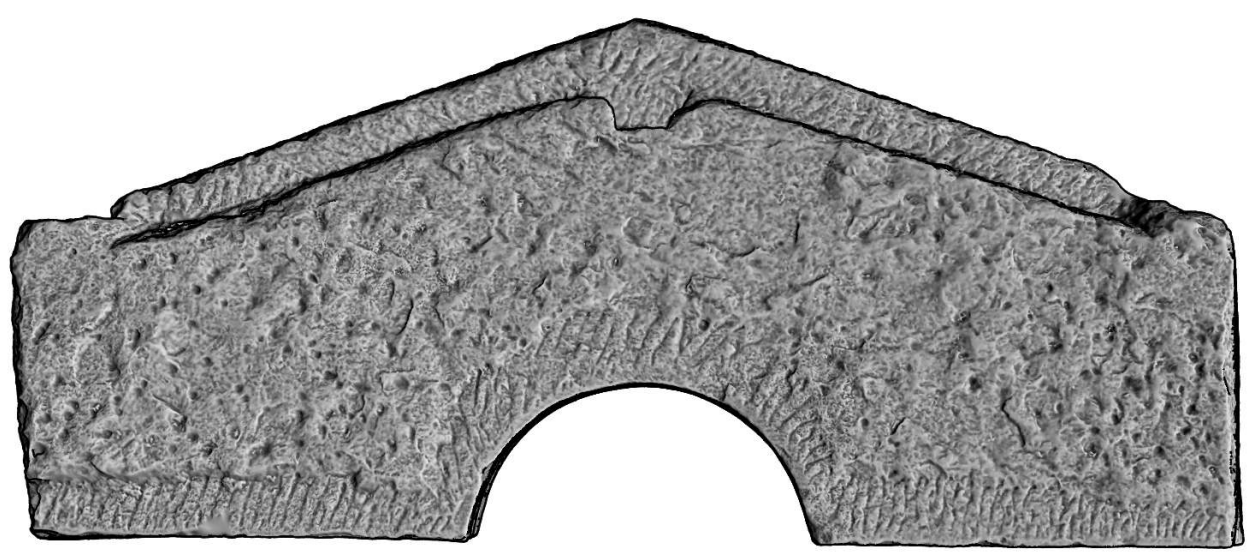

INSCRIPTION OF ASHKELON (BACK OF THE GABLE)

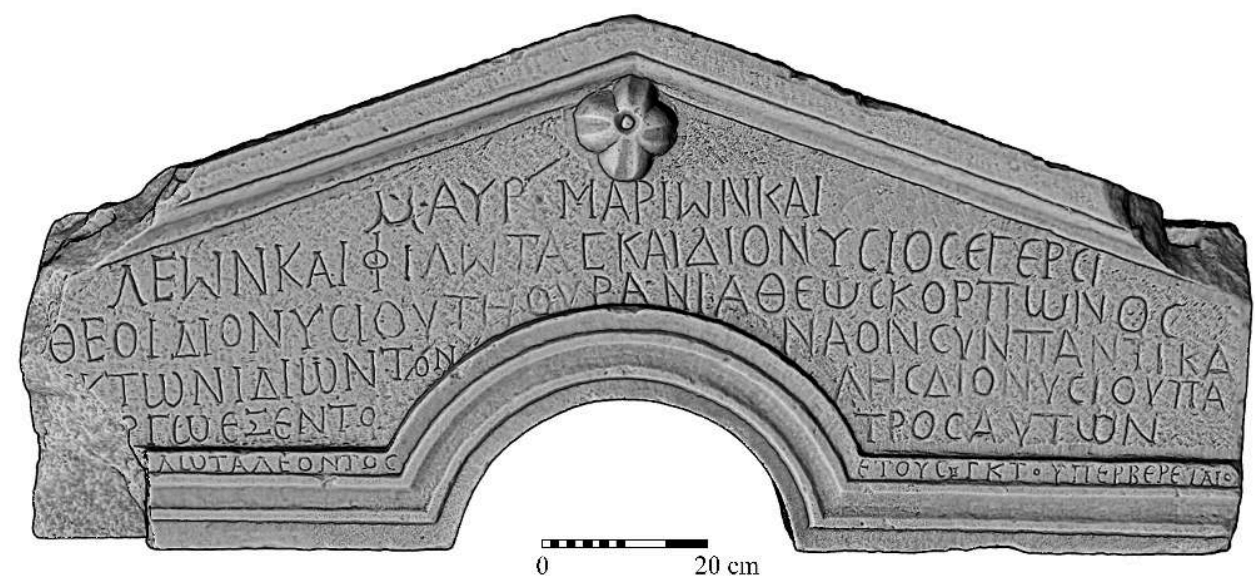

INSCRIPTION OF ASHKELON (INSCRIBED gABLE)

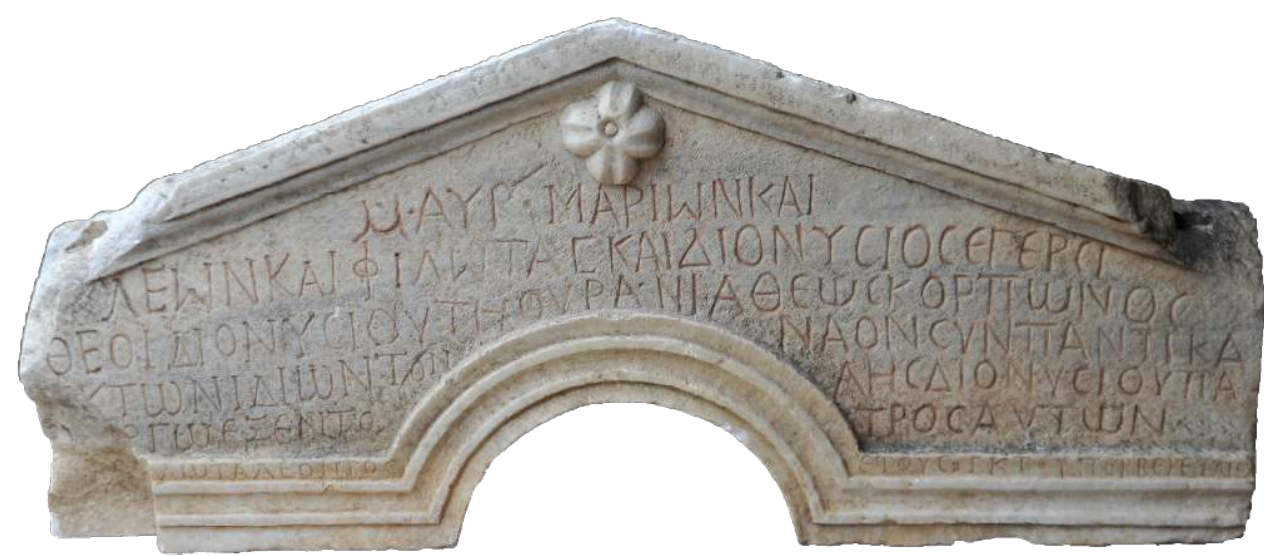

INSCRIPTION OF ASHKELON (INSCRIBED GABLE) 


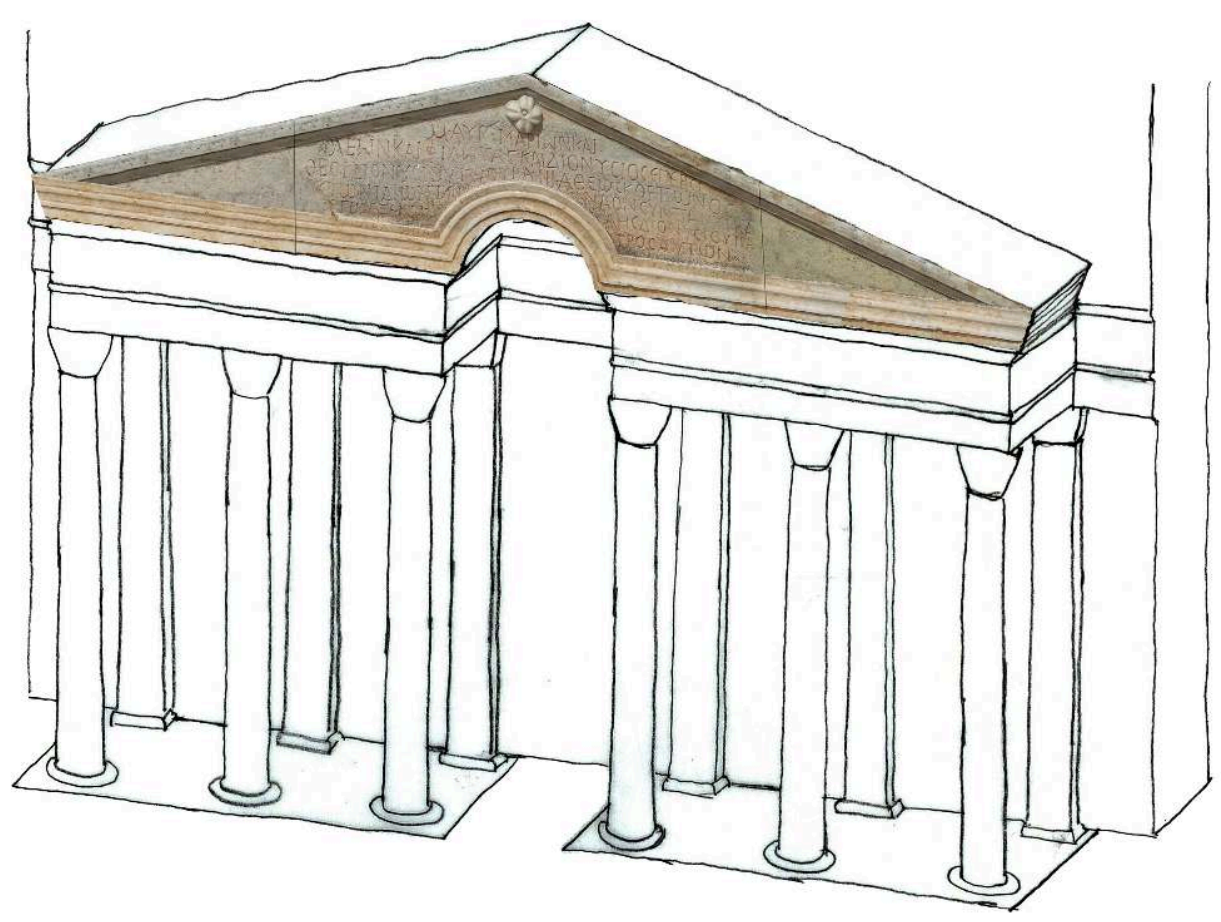

INSCRIPTION OF ASHKELON (RECONSTRUCTION)

\section{BIBLIOGRAPHY}

J. ALIQUOT, “Aegyptiaca et Isiaca de la Phénicie et du Liban aux époques hellénistique et romaine”, Syria 81 (2004), p. 201-228.

M. AVI-YONAH, “The Bath of the Lepers at Scythopolis”, Israel Exploration Journal 13 (1963), p. $325-$ 326.

-, "Sarcophagi from Ascalon", Qadmoniot 27 (1974), p. 106-110.

N. BELAYCHE, Iudaea-Palaestina: the pagan cults in Roman Palestine (second to fourth century), Tübingen, 2001.

R. BOEHM, D.M. MASTER, R. LE BLANC, “The Basilica, Bouleuterion, and Civic Center of Ascalon”, AJA 120 (2016), p. 271-324.

C. BONNET, Melqart. Cultes et mythes de l'Héraclès Tyrien en Méditerranée, Leuven, 1988 (Studia Phoenicia 8).

A.-E. CONTOLEON, S. REINACH, Th. REINACH, “Inscriptions des îles”, REG 17 (1904), p. 196-215.

L. DI SEGNI, Dated Greek Inscriptions from Palestine from the Roman and Byzantine Periods, Jerusalem, 1997 (unpublished PhD dissertation).

G. FinkielszTejn, “Phanébal, déesse d'Ascalon”, Studia Phoenicia 9 (1992), p. 51-58. 
M. FISCHER, "The Basilica of Ascalon: Marble, Imperial Art, and Architecture in Roman Palestine", in J.H. HUMPHREY (ed.), The Roman and Byzantine Near East: Some Recent Archaeological Research, Portsmouth R.I., 1995 (JRA, suppl. 49), p. 121-150.

c. d. FORBIN (Louis Nicholas Philippe Auguste), Travels in Greece and Turkey and the Holy Land in 18171818, London, 1820.

E. FRIEDHEIM, “The Pagan Cults of Ascalon During the Roman Period”, in A. SASSON, Z. SAFRAI, N. SAGIV (eds.), Ascalon: A City on the Seashore, Ascalon, 2001, p. 147-174 (in Hebrew).

G. FUKS, "A Mediterranean Pantheon: Cults and Deities in Hellenistic and Roman Ascalon", MHR 15 (2000), p. 27-48.

A. GILBOA, A. TAL, I. SHIMSHONI, M. KOLOMENKIN, “Computer-Based, Automatic Recording and Illustration of Complex Archaeological Artifacts”, Journal of Archaeological Science 40 (2013), p. 1329-1339.

F. GSCHNITZER, “Eine persische Kultstiftung und die 'Sippengötter' Vorderasiens”, in W. MEID, H. TRENKWALDER (eds.), Im Bannkreis des Alten Orients. Studien zur Sprach- und Kulturgeschichte des Alten Orients und seines Ausstrahlungsraumes Karl Oberhuber zum 70. Geburtstag gewidmet, Innsbruck, 1986, p. 45-54.

R. HACHLILI, Ancient Mosaic Pavements, Leiden, 2009.

G.F. HILL, “Some Palestinian Cults in the Graeco-Roman Age", PBA 5 (1912), p. 419-423.

Y. HUSTER, O. SION, "Built, Vaulted Tombs of the Late Roman and Byzantine Period in the Southern Coastal Plain”, Yerushalaim ve-Eretz-Israel 3 (2006), p. 50-67 (Hebrew).

E. KOGAN-ZEHAVI, “A Painted Tomb from the Roman Period in Migdal Ascalon”, Atiqot 37 (1999), p. 181-209 (Hebrew).

S. KOL-YA'AKOV, Y. FARHI, “Ashqelon (al-Nabi Hussein): Evidence for the Burial of Jews, Christians and Pagans in a Late Roman-Period Burial Ground”, Atiqot 70 (2012), p. 87-111 (Hebrew).

E. MEIMARIS, Chronological systems in Roman-Byzantine Palestine and Arabia: the evidence of the dated

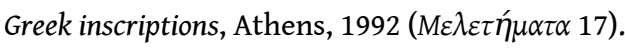

J. ORY, “A Painted Tomb Near Ascalon", Quarterly of the Department of Antiquities in Palestine (QDAP) 8 (1939), p. 38-44.

R. PALISTRANT SHAICK, “Who is Standing Above the Lions in Ascalon?", Israel Numismatic Research 7 (2012), p. 127-146.

N. ROBERTSON, "The Ritual Background of the Dying God in Cyprus and Syro-Palestine", HThR 75 (1982), p. 313-359.

B. SARIDAKIS, F. HILLER VON GÄRTRINGEN, "Inschriften aus Syme, Teutlussa und Rhodos”, JÖAI 7 (1904), p. 81-94.

D.J. sCHLOEN, “Early Explorations", in L.E. STAGER, D.J. SCHLOEN, D.M. MASTER (eds.), Ascalon 1: Introduction and Overview (1985-2006), Winona Lake, Indiana, 2008, p. 143-152.

-, "British and Israeli Excavations", in L.E. STAGER, D.J. SCHLOEN, D.M. MASTER (eds.), Ascalon 1: Introduction and Overview (1985-2006), Winona Lake, Indiana, 2008, p. 153-155.

A. SEGAL, Temples and Sanctuaries in the Roman East, Oxford, 2013. 
Y. USTINOVA, “Aphrodite Ourania of the Bosporus: The Great Goddess of a Frontier Pantheon", Kernos 11 (1998), p. 209-226.

A.J.M. WEDDERBURN, Baptism and Resurrection: Studies in Pauline Theology against Its Graeco-Roman Background, Tübingen, 1987.

\section{NOTES}

1. "Not far from the Gothic monuments of Ascalon are to be seen the extensive monuments of the temple of Venus: forty lofty columns of Rose Granite, and capitals and friezes of the finest marble, rise from a deep vault half laid open", FORBIN (1820), p. 159.

2. Clues for a temple may perhaps be picked out from the descriptions of nineteenth-century documentation and unscientific excavations at Ascalon, but these go beyond the scope of this paper. See SCHLOEN (2008). For others, see FISCHER (1995); BOEHM, MASTER, LE BLANC (2016); SCHLOEN (2008); ORY (1939); AVI-YONAH (1974); KOGAN-ZEHAVI (1999); HUSTER, SION (2006); KOL-YA'AKOV, FARHI (2012).

3. For similar niches in temple façades see SEGAL (2013), no. 31: Mismiyeh (Masmiye, Musmieh), no. 33: Is Sanamen (Sanamein), no.39: Brekeh (Boureike). For free-standing aedicules in Palestine, see HACHLILI (2009), p. 23-28, where we find synagogue Torah shrines depicted in floor mosaics of the $4^{\text {th }}-6^{\text {th }}$ centuries. Cf. SEG 20, 457 for an inscription which may have stood at the top of an aedicule from Beit Shean (Scythopolis).

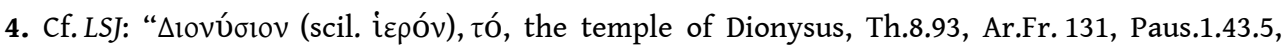
etc."

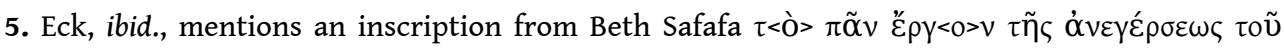
olkov (SEG 16, $850=26,1672)$, and refers to Herodian 8.5.4: "Maximinus' soldiers met with serious

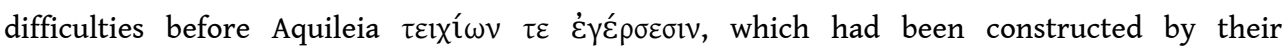
opponents."

6. See esp. Josephus AJ 8.145-146, cont. Apion. 1.117-119; BONNET (1988), p. 33-40, 104-112.

7. BONNET (1988), p. 174-179.

8. BONNET (1988), p. 131-132.

9. ROBERTSON (1982), p. 193-195; WEDDERBURN (1987), p. 193-195

10. CONTOLEON, REINACH, REINACH (1904), p. 204-210, esp. p. 209-210; SARIDAKIS, HILLER VON GÄRTRINGEN (1904), p. 92-94.

11. See AliQuot (2004), esp. p. 212-213.

12. On personal names in the genitive accompanying the name of a deity and designating the cult founder, see GSCHNITZER (1986), p. 45-54.

13. AVI-YONA (1963) (= DI SEGNI [1997], no. 114).

14. MEIMARIS (1992), p. 66f.

15. For a study tracing the cult of Aphrodite Ourania from its inception see USTINOVA (1998).

16. IDélos: 1719, 2305.

17. Pausanias 1.14.7. The cults of Ascalon, including their manifestation on the city coins, have been surveyed and analyzed by several scholars, starting with HILL (1912); and much more recently FINKIELSZTEJN (1992); FUKS (2000); BELAYCHE (2001), p. 220-232; FRIEDHEIM (2001); PALISTRANT SHAICK (2012). 


\section{ABSTRACTS}

An inscribed marble gable found near the ancient city center of Ascalon (modern Ashkelon) is published. The inscription ( of $\mathrm{AD} 220$ ) records the erection and dedication of a temple in honor of the goddess "Ourania of Skorpon". Ourania Aphrodite was a resident deity in Ascalon and this appears to be the first tangible piece of evidence confirming the ancient ties linking her to the city. The word egersitheos, revivifier of a deity, in this inscription is otherwise unattested.

Publication d'un fronton en marbre trouvé près du centre de l'ancienne ville d'Ascalon (aujourd'hui Ashkelon). L'inscription (datée de 220 ap. J.-C.) évoque la construction et la dédicace d'un temple en l'honneur de la déesse "Ourania de Skorpon". Aphrodite Ourania était une divinité locale à Ascalon, et ce fragment semble bien être la première attestation matérielle confirmant les liens anciens entre la déesse et la ville. Le mot egersitheos, « celui qui revivifie une divinité », n'est pas attesté ailleurs.

\section{AUTHORS}

\section{AVNER ECKER}

The Martin (Szusz) Department of Land of Israel Studies and Archaeology, Bar-Ilan University avner.ecker@biu.ac.il

HANNAH M. COTTON

Department of Classics, The Hebrew University of Jerusalem, Jerusalem 91905 hannah.cotton@mail.huji.ac.il

\section{SAAR GANOR}

Ascalon District Archaeologist, Israel Antiquities Authority, P.O. Box 271, Omer 84965, Israel saarg@israntique.org.il

\section{DAVID J. WASSERSTEIN}

Vanderbilt University, Department of History, PMB 351802, 2301 Vanderbilt Place, Nashville, TN 37235-1802, USA

david.wasserstein@Vanderbilt.Edu 